\title{
Isolation and Identification of Bacterial Strains from Yamuna River at Allahabad District in Uttar Pradesh, India
}

\author{
Anurag Kumar ${ }^{1 *}$, Jane Claryn Benjamin ${ }^{1}$, Arti Kumari ${ }^{2}$ and Hemant Kumar ${ }^{3}$ \\ ${ }^{1}$ Department of Industrial Microbiology, Jacob Institute of Biotechnology and Bio- \\ Engineering, ${ }^{2}$ Faculty of Health Sciences, ${ }^{3}$ College of Forestry, \\ SHUATS, Allahabad - 211007, U.P., India \\ *Corresponding author
}

\author{
A B S T R A C T
}

\section{Keywords}

River Yamuna, Water pollution, Salmonella spp, Vibrio spp, Isolation, Identification

Article Info

Accepted:

20 November 2018

Available Online:

10 December 2018
The aim of this work was to detect the presence of bacterial species in Yamuna river water from six different sites namely $\left(S_{1}\right)$ Mahewa Ghat, $\left(S_{2}\right)$ Gau Ghat, $\left(S_{3}\right)$ Old Naini Bridge, $\left(\mathrm{S}_{4}\right)$ New Naini Bridge, $\left(\mathrm{S}_{5}\right)$ Arail Ghat, $\left(\mathrm{S}_{6}\right)$ Saraswati Ghat. Total 36 samples of water were used for isolation purpose. Salmonella were detected in 5 samples with highest ranking (13.9\%). Salmonella spp. isolates belonged to the species $S$. typhi (two isolates), S. enterica, S. choleraesuis, S. gallinarum while Vibrio were detected in 4 samples (11.2\%). Vibrio spp. isolates belonged to the following species $V$. cholera (two isolates), V. parahaemolyticus, $V$. navarrensis. The presence of bacteria species indicates the pollution status, due to the sewage, human activities and industrial activities etc, the quality of river water has deteriorated which affects human as well as aquatic life.

\section{Introduction}

Yamuna is one of the most polluted rivers in India, especially around Delhi, because of the large amount of the wastewater discharge. According to the Centre for Science and Environment, approximately 75 to 80 percent of the river's pollution is the result of raw sewage, industrial runoff and the garbage thrown into the river and it totals over 3 billion litres of waste per day (Mishra, 2010 and Martínez et al., 2009). Today water resources have become the most exploited natural system since man strode the earth.
According to united nation report, freshwater is gradually becoming a matter of concern with nearly 900 million people affected by diarrhoea each year and an equal number suffering from disease caused by various worm. Unclean water ranks at top of the world population problem (Goel and Grad, 2008). The industrial pollutants associated with organic matter, inorganic dissolved solids and other unwanted chemicals cause serious problems in the water quality (Radha et al., 2007). Water quality can also be evaluated through chemical and physical parameters 
including heavy metals, trace metals, total suspended solid and turbidity. These trace elements present in virtually potable water, some of which play a role in metabolism. Major ions in drinking water are correlated with palatable mineralization that affects the quality of drinking water (Delpla et al., 2009). Water of good quality is of basic importance to human physiology and man's continued existence depends very much on its availability (Lamikanra et al., 1999; Ottaviani et. al., 2005). Pathogens such as Salmonella spp, Vibrio cholera and E.coli that are shed into water body through faecal contamination perpetuate many diseases (Faparusi et al., 2011). These cause typhoid fever and dysentery. Other agents of water borne diseases are protozoan that cause diarrhoea; Entamoeba histolytica, Giardia lamblia, Balantidium coli and Cryptococcus pervum (Kelly et al., 1997). Salmonella is a ubiquitous enteric pathogen with a worldwide distribution that comprises a large number of serovars characterized by different host specificity and distribution (Pond, 2005) just like other enteric bacteria, Salmonella is spread by the fecal-oral route of contamination. This microorganism can enter the aquatic environment directly with feces of infected humans or animals or indirectly, e.g., via sewage discharge or agricultural land run off (Wray et al., 2000; Lightfoot et al., 2004; Dolejska et al., 2009). Salmonellae are frequently found in environmental samples. They $\left(10^{3}-10^{4}\right)$ are usually present in large numbers in raw sewage CFU/L) and can still be present in wastewater effluent after advanced secondary treatment including coagulation, filtration and disinfection (Maier et al., 2000; Wéry et al., 2008). Temporal and spatial variation of Salmonella frequencies have been commonly observed in surface water (Lemarchand and Lebaron, 2003; Bonadonna et al., 2006; Meinersmann et al., 2008; Till et al., 2008; Byappanahalli et al., 2009; Haley et al., 2009; Wilkes et al., 2009;
Jokinen et al., 2010). It is possible that variations in the occurrence of Salmonella in ambient water may be governed, in part, by environmental parameters such as temperature, water chemistry, and solar radiation that influence survival and transport of the microorganism (Polo et al., 1999; Baudart et al., 2000; Schets et al., 2008; Wilkes et al., 2009). Vibrios are primarily aquatic bacteria. Species distribution depends on sodium concentration and water temperature (Farmer and Hickam-Brenner, 2003). Vibrios are autochthonous to the oceanic, estuarine, and freshwater ecosystem (Kaneko and Colwell, 1973). They are found in sediments (Vezzulli et al., 2009) and are known to produce bio-films on surfaces. They either swim freely in the water column, or adhere to associated with other organisms. Moreover, ample numbers of Vibrio species have developed adaptive features that enable them to predominantly thrive in salty and even river environments (Hood and Winter, 1997; Mccarter, 1999; Lipp et al., 2002; Thompson et al., 2004; Grau et al., 2005; Pruzzo et al., 2005). Several investigations have also shown the prevalence of Vibrio species in surface water throughout the world, and their prevalence in the environment is influenced by season and location (Johnson et al., 2012). They are usually linked to eruptions of Vibrio infections as a result of consuming undercooked seafood and water contaminated with sewage (Lee et al., 2002).Vibrio species have been reported to be capable of surviving in many different environmental conditions due to the development of a spectrum of adaptive responses to nutrient deficit, variations in salinity and temperature, and a resistance to predation by heterotrophic protists and bacteriophage (Colwell, 2009). Numerous studies that have investigated the distribution of Vibrio species suggest that pathogenic subpopulations of the genus Vibrio are potential reservoirs for disease epidemics (Lutz et al., 2014). Previous studies have 
established that it is almost impossible to understand the effect of single physic chemical parameters on Vibrio species since all parameters are interdependent and the influence of the environmental conditions varies from one species to another. The incidence and the rate distribution of Vibrio species have been linked to a vast array of environmental factors, most notably organic matter, salinity, temperature, and the association with aquatic animals depending on the pathogen and its habitat, and the geographic location (Cavallo and Stabili, 2002; Janelidze et al., 2011; Jaiani et al., 2013; Arunagiri et al., 2013). Developing countries are extremely affected because of their paucity of resources, infrastructure and disaster awareness systems (Sur, 2000). The aim of this work was to detect the presence of Salmonella spp. and Vibrio spp. from Yamuna river water.

\section{Materials and Methods}

\section{Study area}

The study area was divided into six sampling sites (Table 1). River water samples were collected from six sampling sites from area Allahabad district as $\left(\mathrm{S}_{1}\right)$ Mahewa Ghat, $\left(\mathrm{S}_{2}\right)$ Gau Ghat, $\left(\mathrm{S}_{3}\right)$ Old Naini Bridge, $\left(\mathrm{S}_{4}\right)$ New Naini Bridge, $\left(\mathrm{S}_{5}\right)$ Arail Ghat, $\left(\mathrm{S}_{6}\right)$ Saraswati Ghat.

\section{Collection of water sample}

The Yamuna river water samples were collected during April to September 2016 from the Mahewa Ghat to Saraswati Ghat for the assessment of physico-chemical factors. River water Samples were collected (3 Times) of every month in BOD bottles and sterile one litter politeness bottles. The closed bottles were immersed in the river at the depth of 0.5 to $0.7 \mathrm{~m}$ and the stopper was opened in bottom of river and was closed again to the river water. After sample collection, the bottles were kept in ice box and transferred immediately to the laboratory for further analyses (Sivamanikandan and Ahmed john, 2015). Total 36 water samples were used for Salmonella spp. and Vibrio spp. isolation and identification purpose.

\section{Isolation of Salmonella}

$1 \mathrm{ml}$ of water sample was inoculated in $9 \mathrm{ml}$ of buffered peptone water and incubated at $37^{\circ} \mathrm{C}$ for $18 \mathrm{hrs}$ for pre-enrichment. After enrichment, a loopful of inoculums was then streaked on xylose lysine desoxycholate (XLD) agar and incubated at $37^{\circ} \mathrm{C}$ for $24 \mathrm{~h}$. The presumptive Salmonella colonies appearing slightly transparent red halo with a black centre surrounded by a pink-red zone on XLD agar and were sub-cultured and for each sample, a representative pure colony was selected and stored on sterile nutrient agar, colonies were confirmed by gram staining and biochemical characterization.

\section{Isolation of Vibrio}

$1 \mathrm{ml}$ of water sample was inoculated in $9 \mathrm{ml}$ of alkaline peptone water and incubated at $37^{\circ} \mathrm{C}$ for $8 \mathrm{~h}$ for pre-enrichment. After enrichment, a loopful of inoculums was then streaked on thiosulphate citrate bile salt sucrose (TCBS) agar and incubated at $37^{\circ} \mathrm{C}$ for $24 \mathrm{~h}$. Yellow smooth and slightly flattened colonies with opaque centers and translucent peripheries appearing after $24 \mathrm{~h}$ of incubation were presumably considered as Vibrio species and were sub-cultured and for each sample, a representative pure colony was selected and stored on sterile nutrient agar, colonies were confirmed by gram staining and biochemical characterization.

\section{Morphological analysis}

The pure culture obtained was then observed for colony and other morphological characteristics, the culture was gram stained.

Biochemical analysis 
Gram Staining, Motility, Urease, ONPG, Catalase, Oxidase, Indole production, Voges Proskauer, Nitrate Reduction, Citrate Utilization, String (for Vibrio), $\mathrm{H}_{2} \mathrm{~S}$, Methyl Red test was used for both colonies of Salmonella spp ans Vibrio spp as described Bergey's Manual of Systematic Bacteriology.

\section{Results and Discussion}

Out of total 36 water samples analyzed. Origins and numbers of samples in each of them are presented in the Table 1. Salmonella were detected in 5 samples $(13.9 \%)$ and Vibrio were detected in 4 samples $(11.2 \%)$. The site with highest incidence was the Gau Ghat, where the Salmonella organism was found in 3 samples, followed by Arail Ghat, and Mahewa Ghat with one strain each one. The site with highest incidence was the, Mahewa Ghat where the Vibrio organism was found in 2 samples, followed by Arail Ghat, and Gau Ghat with one strain each one. Both the organisms were found motile and strictly aerobic.

Results for Salmonella spp. motility, catalase, nitrate $\mathrm{MR}, \mathrm{H}_{2} \mathrm{~S}$ reaction are found positive and similar results have been reported by (Nesaet al., 2011; Khan et al., 2007), the negative results of Voges-Proskauer and Indole, urease, ONPG, oxidase, citrate. The carbohydrate profile of the bacteria under investigation depicts that it could utilize glucose, maltose and mannitol with weak production of acid and little or no gas production; but could not utilize xylose, lactose, sucrose and arabinose. Similar results have been reported by Meinersmann et al., (2008).

Results for Vibrio spp. motility, string, citrate, indole, oxidase, ONPG, nitrate reaction are found positive the negative results of $\mathrm{MR}, \mathrm{H}_{2} \mathrm{~S}$ and urease. The carbohydrate profile of the bacteria under investigation depicts that it could utilize glucose, maltose and mannitol with weak production of acid and little or no gas production; but could not utilize xylose, lactose, sucrose and arabinose. Similar results have been reported by Kaper et al., (1980). Results for Vibrio spp. motility, string, citrate, indole, oxidase, ONPG, nitrate reactions are found positive the negative results of $\mathrm{MR}, \mathrm{H}_{2} \mathrm{~S}$ and urease.

The carbohydrate profile of the bacteria under investigation depicts that it could utilize glucose, maltose and mannitol with weak production of acid and little or no gas production; but could not utilize xylose, lactose, sucrose and arabinose. Similar results have been reported by (Kaper et al., 1980) (Table 2-5).

Table.1 Geographical location of water sampling sites

\begin{tabular}{|l|c|c|}
\multicolumn{1}{c|}{ Site } & Latitude & Longitude \\
\hline MahewaGhat & $25^{\circ} 25^{\prime} 2^{\prime \prime} \mathrm{N}$ & $81^{\circ} 50^{\prime} 18^{\prime \prime} \mathrm{E}$ \\
\hline GauGhat & $25^{\circ} 25^{\prime} 27^{\prime \prime} \mathrm{N}$ & $81^{\circ} 50^{\prime} 45^{\prime \prime} \mathrm{E}$ \\
\hline Old Naini Bridge & $25^{\circ} 25^{\prime} 37^{\prime \prime} \mathrm{N}$ & $81^{\circ} 50^{\prime} 59^{\prime \prime} \mathrm{E}$ \\
\hline New NainiBridge & $25^{\circ} 25^{\prime} 25^{\prime \prime} \mathrm{N}$ & $81^{\circ} 51^{\prime} 41^{\prime \prime} \mathrm{E}$ \\
\hline ArailGhat & $25^{\circ} 25^{\prime} 18^{\prime \prime} \mathrm{N}$ & $81^{\circ} 52^{\prime} 54^{\prime \prime} \mathrm{E}$ \\
\hline SaraswatiGhat & $25^{\circ} 25^{\prime} 50^{\prime \prime} \mathrm{N}$ & $81^{\circ} 52^{\prime} 6^{\prime \prime} \mathrm{E}$ \\
\hline
\end{tabular}


Table.2 Origins and numbers of samples

\begin{tabular}{|l|}
\hline Site of sampling \\
\hline Mahewa Ghat \\
\hline Gau Ghat \\
\hline Old Naini Bridge \\
\hline New Naini Bridge \\
\hline Arail Ghat \\
\hline Saraswati Ghat \\
\hline Total \\
\hline
\end{tabular}

\begin{tabular}{|l|c|}
\hline Type of site & Number of samples \\
\hline River & 6 \\
\hline River & 6 \\
\hline River & 6 \\
\hline River & 6 \\
\hline River & 6 \\
\hline River & 6 \\
\hline
\end{tabular}

Table.3 Occurrence \% of Salmonella spp and Vibrio spp from Yamuna river

\begin{tabular}{|c|c|c|}
\hline $\begin{array}{c}\text { No. of } \\
\text { Water samples }\end{array}$ & No. of Salmonella spp & No. of Vibrio spp \\
\hline 36 & $5(13.9 \%)$ & $4(11.2 \%)$ \\
\hline
\end{tabular}

Table.4 Cultural and Morphological analysis for Salmonella typhi and vibrio cholera

\begin{tabular}{|c|c|c|c|}
\hline & Characteristics & XLD Agar & TCBS Agar \\
\hline & Colour & Red with Black dots & Yellow, blue to black \\
\hline & Margin & Regular & Regular \\
\hline & Elevation & Convex & Umbonate \\
\hline & Opacity & Opaque & Opaque \\
\hline & Pigmentation & Red and Black & Yellow \\
\hline & Size (in mm) & $0.5-0.7$ & $1-2$ \\
\hline & Texture & Butyrus & Butyrus \\
\hline & Staining & Gram's & Gram's \\
\hline & Reaction & -ve & -ve \\
\hline & Shape & Rod & Curved(comma) \\
\hline
\end{tabular}

Table.5 Sugar fermentation test for Salmonella typhi and Vibrio cholera

\begin{tabular}{|c|c|c|c|c|c|}
\hline \multirow[t]{2}{*}{ S. No } & \multirow[t]{2}{*}{ Carbohydrates } & \multicolumn{2}{|c|}{ S.typhi } & \multicolumn{2}{|c|}{ V.cholerae } \\
\hline & & Acid & Gas & Acid & Gas \\
\hline 1 & Arabinose & -ve & -ve & $+{ }^{\mathrm{ve}}$ & $+{ }^{\mathrm{ve}}$ \\
\hline 2 & Lactose & -ve & - ve & - ve & - ve $^{2}$ \\
\hline 3 & Maltose & $+{ }^{\mathrm{ve}}$ & $+{ }^{\mathrm{ve}}$ & $+{ }^{\mathrm{ve}}$ & $+{ }^{\mathrm{ve}}$ \\
\hline 4 & Mannitol & $+{ }^{\mathrm{ve}}$ & $+{ }^{\mathrm{ve}}$ & $-{ }^{\text {ve }}$ & - ve \\
\hline 5 & Sucrose & -ve & $-{ }^{\mathrm{ve}}$ & $-{ }^{\text {ve }}$ & $-{ }^{\mathrm{ve}}$ \\
\hline 6 & Xylose & $+{ }^{\mathrm{ve}}$ & - ve & - ve & $-{ }^{\mathrm{ve}}$ \\
\hline 7 & Glucose & $+{ }^{\mathrm{ve}}$ & $+{ }^{\mathrm{ve}}$ & $+{ }^{\mathrm{ve}}$ & $+{ }^{\mathrm{ve}}$ \\
\hline
\end{tabular}


Table.6 Biochemical analysis of Salmonella typhi and Vibrio cholera

\begin{tabular}{|c|c|c|c|}
\hline \multirow{14}{*}{ 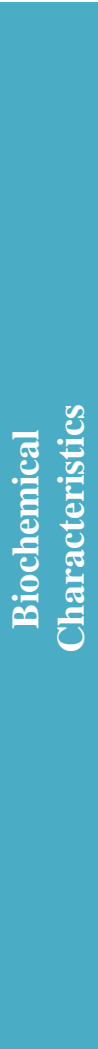 } & Name of the test & $\begin{array}{c}\text { Salmonella } \\
\text { typhi }\end{array}$ & Vibrio cholerae \\
\hline & Gram Staining & -ve & -ve \\
\hline & Motility & + ve & $+v e$ \\
\hline & Urease & -ve & -ve \\
\hline & ONPG & -ve & $+\mathrm{ve}$ \\
\hline & Catalase & $+\mathrm{ve}$ & -ve \\
\hline & Oxidase & - ve & $+\mathrm{ve}$ \\
\hline & Indole production & - ve & $+\mathrm{ve}$ \\
\hline & Voges-Proskauer & -ve & -ve \\
\hline & Nitrate reduction & + ve & $+\mathrm{ve}$ \\
\hline & Citrate utilization & -ve & -ve \\
\hline & String & - & $+\mathrm{ve}$ \\
\hline & $\mathrm{H}_{2} \mathrm{~S}$ & $+\mathrm{ve}$ & -ve \\
\hline & Methyl Red & $+\mathrm{ve}$ & -ve \\
\hline
\end{tabular}

The biochemical properties were estimated using Bergey's Mannual of Systematic Bacteriology. Results for Vibriospp. motility, string, citrate, indole, oxidase, ONPG, nitrate reaction are found positive the negative results of $\mathrm{MR}, \mathrm{H}_{2} \mathrm{~S}$ and urease. The carbohydrate profile of the bacteria under investigation depicts that it could utilize glucose, maltose and mannitol with weak production of acid and little or no gas production; but could not utilize xylose, lactose, sucrose and arabinose. Similar results have been reported by (kaper et al., 1980). The biochemical properties were estimated using Bergey's Mannual of Systematic Bacteriology (Table 6).

The isolation of Salmonella spp. and Vibrio spp. from water sample means that the direct consumption of such water without treatment
May be very risky. This study reveals that contamination of Yamuna water is by humans and other animal sources like bathing, farming and washing.

In conclusion, present study confirmed the presence of Escherichia coli, Salmonella spp, and Vibrio spp.as water-borne pathogens in Yamuna water of Allahabad district in Uttar Pradesh, India. It also showed the important public health problem in of Allahabad district in Uttar Pradesh, India. The result of this study revealed that the water sources in these communities are moderate polluted and is not safe for use by the communities for drinking or other domestic needs without prior treatment. There is need to monitor regularly and mitigate the effects of community behaviour on surface waters. 


\section{References}

Arunagiri, K; Jayashree, K; Sivakumar, T. (2013). Isolation and identification of Vibrios from marine food resources. Int. J. Curr. Microbiol. App Sci, 2, 217-232.

Baudart, J., Lemarchand, K., Brisabois, A., and Lebaron, P. (2000). Diversity of Salmonella strains isolated from the aquatic environment as determined by serotyping and amplification of the ribosomal DNA spacer regions. Applied and Environmental Microbiology, 66, 1544-1552.

Bonadonna, L., Filetici, E., Nusca, A., and Paradiso, R. (2006). Controlli ambientali sulla diffusione di sierotipi di Salmonella spp in acque fluviali. Microbiologia Medica, 21(4), 311-315.

Byappanahalli, M. N., Sawdey, R., Ishii, S., Shively, D. A., Ferguson, J. A., Whitman, R. L., et al. (2009). Seasonal stability of Cladophora-associated Salmonella in Lake Michigan watersheds. Water Research, 43, 806814.

Cavallo, R.A; Stabili, L. (2002) Presence of vibrios in seawater and Mytilus galloprovincialis (Lam) from the Mar Piccolo of Taranto (Ionian Sea). Water Res, 36, 3719-3726.

Colwell, R.R. (2009). Predicting the distribution of Vibrio spp. in the Chesapeake bay: A Vibrio cholerae case study. Eco Health, 6, 378-389.

Delpla I., Jung A. V., Baures E., Clement M. and Thomas O. (2009). Impact of climate on surface water quality in relation to drinking water production. Environmental International, 35(8), 225-1233.

Dolejská, M., Bierosová, B., Kohoutová, L., Literák, I., and Cízek, A. (2009). Antibiotic resistant Salmonella and Escherichia coli isolates with integrons and extended-spectrum beta-lactamases in surface water and sympatric blackheaded gulls. Journal of Applied Microbiology, 106(6), 1941-1950.

Faparusi F., Ayedun H. and Bello-Akinosho M. M. (2011). Microbial and physicochemical properties of ground water of Ilaro, South-West, Nigeria. International Journal of Biological and Chemical Sciences, 5(2), 500-506.

Farmer, J.J and Hickam-Brenner, F.W. (2003). The Genus Vibrio and Phtotobacterium. In The Prokaryotes: An Evolving Electronic Resource for the Microbiological Community, electronic release 3.14, 3th ed.; Dworkin, M., Falkow, S., Rosenberg, E., Eds.; Springer-Verlag: New-York, NY, USA.

Goel, V; Grad I.E; Kumar. A and Verma. K; (2008). Quantitative Study on Microbial Pollution of River Yamuna at Delhi. IE(I) Journal-Environment 88, March 2008.

Grau, B.L; Henk, M.C; Pettis, G.S (2005 ).High-frequency phase variation of Vibrio vulnificus 1003: Isolation and characterization of a rugose phenotypic variant. J. Bacteriol, 187, 2519-2525.

Haley, B. J., Cole, D. J., and Lipp, E. K. (2009). Distribution, diversity and seasonality of water-borne Salmonella in a rural watershed. Applied and Environmental Microbiology,75, 12481255.

Hood, M.A; Winter, P.A (1997). Attachment of Vibrio cholerae under various environmental conditions and to selected substrates. FEMS Microbiol. Ecol., 22, 215-223.

Kaper. J. B., Remmers. E. F., and Colwell. R. R. (1980). A Medium for Presumptive Identification of Vibrio parahaemolyticus. Journal of Food Protection.

Jaiani, E; Kokashvili, T; Mitaishvili, N; Elbakidze, T; Janelidze, N; Lashkhi, N; Kalandadze, R;Mikashavidze, E; 
Natroshvili, G; Whitehouse, C.A. (2013). Microbial water quality of recreational lakes near Tbilisi, Georgia. J. Water Health 11, 333-345.

Janelidze, N; Jaiani, E; Lashkhi, N; Tskhvediani, A; Kokashvili, T; Gvarishvili, T; Jgenti, D; Mikashavidze, E; Diasamidze, R; Narodny, S.(2011) Microbial water quality of the Georgian coastal zone of the Black Sea. Mar. Pollut. Bull,62, 573-580.

Johnson, C.N; Bowers, J.C; Griffitt, K.J; Molina, V; Clostio, R.W; Pei, S; Laws, E; Paranjpye, R.N; Strom, M.S; Chen, A; et al.(2012). Ecology of Vibrio parahaemolyticus and Vibrio vulnificus in the coastal and estuarine waters of Louisiana, Maryland, Mississippi, and Washington (United States). Appl. Environ. Microbiol,78, 7249-7257.

Jokinen, C. C., Schreier, H., Mauro, W., Taboada, E., Isaac-Renton, J. L., Topp, E., et al. (2010). The occurrence and sources of Campylobacter spp, Salmonella enteric and Escherichia coli O157:H7 in the Salmon River, British Columbia, Canada. Journal of Water and Health, 8, 374-386.

Kaneko, T; Colwell, R.R (1973). Ecology of Vibrio parahaemolyticus in Chesapeake Bay. J. Bacteriol,113, 24-32.

Kelly P., Baboo P., Ndubani M and Okeowo, M. P. (1997). Cryptosporidiosis in adult in Lukasa, Zambia and its relationship to oocyst contamination of drinking water. The Journal of Infectious Diseases, 176, 1120- 1123.

Khan A. A, Melvin C. D and Dagdag E. B.(2007). Identification and molecular characterization of Salmonella spp. from unpasteurized orange juices and identification of new serotype Salmonella strain $S$. enterica serovar Tempe. Food Microbiology, 24(5), 3943.

Lamikanra A.(1999).Essential Microbiology for Students and Practitioner of Pharmacy, Medicine and Microbiology. 2nd ed. Amkra books, Lagos, 406.

Lee, S.K; Wang, H.Z; Law, S.H; Wu, R.S; Kong, R.Y.(2002).Analysis of the 16S23S rDNA intergenic spacers (IGSs) of marine vibrios for species-specific signature DNA sequences. Mar. Pollut. Bull,44, 412-420.

Lemarchand, K., and Lebaron, P. (2003). Occurrence of Salmonella spp. and Cryptosporidium spp. in a French coastal watershed: Relationship with faecal indicators. FEMS Microbiology Letters, 218(1), 203-209.

Lightfoot, D. (2004). Salmonella and other enteric organisms. In J. A. Cotruvo, A. Dufour, G. Rees, J. Bartram, R. Carr, D. O. Cliver, G. F. Craun, R. Fayer, and V. P. J. Gannon (Eds.),Water-borne zoonoses identification, causes, and control (pp. 228-241). London: IWA Publishing, World Health Organization.

Lipp, E.K; Huq, A; Colwell, R.R. (2002). Effects of global climate on infectious disease: The cholera model. Clin. Microbiol. Rev, 15, 757-770.

Lutz, S; Anesio, A.M; Villar, S.E.J; Benning, L.G. (2014). Variations of algal communities cause darkening of a Greenland glacier. FEMS Microbiol. Ecol, 89, 402-414.

Maier, R., Pepper, I., and Gerba, C.(2000). Environmental microbiology. Orlando, Florida: Academic Press.

Martínez, R, A., Fonseca, G, K., Ortega, S., J.L. and Garcia. L., C. (2009). Monitoreo de la Calidad Microbiológica del Agua en la Cuenca Hidro- lógica del Río Nazas, México. Revista Química Viva, 1, 35-47.

Mccarter,L.(1999). The multiple identities of Vibrio parahaemolyticus. J. Mol. Microbiol. Biotechnol, 1, 51-57.

Meinersmann, R. J., Berrang, M. E., Jackson, C. R., Fedorka-Cray, P., Ladely, S., 
Little, E., et al. (2008). Salmonella, Campylobacter and Enterococcus spp. Their antimicrobial resistance profiles and their spatial relationships in a synoptic study of the upper Oconee River basin. Microbial Ecology, 55(3), 444-452.

Misra A. K. (2010).A River about to die: Yamuna. Journal of water Resource and Protection, 2(5), 12.

Nesa M. K., Khan M. S. R. and Alam M. (2011). Isolation, identification and characterization of salmonella serovars from diarrhoeic stool samples of human. Bangladesh Journal of Veterinary Medicine, 9(1), 85 - 93.

Ottaviani D., Santarelli S., Bacchiocchi S., Masini L., Ghittino C. and Bacchiocchi I. (2005). Presence of pathogenic Vibrio parahaemolyticus strains in mussels from the Adriatic Sea, Italy Food Microbiology, 22(6), 585-90.

Polo, F., Figueras, M. J., Inza, I., Sala, J., Fleisher, J. M., and Guarro, J. (1999). Prevalence of Salmonella serotypes in environmental waters and their relationships with indicator organisms. Antonie Van Leeuwenhoek, 75, 285292.

Pond, K. (2005). Water recreation and disease infections: Plausibility of associated acute effects, sequelae and mortality. London: IWA Publishing, World Health Organization.

Pruzzo, C; Huq, A; Colwell, R.R and Donelli, G. (2005).Pathogenic Vibrio species in the marine and estuarine environment. In Ocean and Health Pathogens in the Marine Environment; Belkin, S., Colwell, R.R., Eds.; Springer: New York, NY, USA, pp. 217-252.

Radha. R., Dharmaraj.K., and Ranjitha., B.D. (2007). A Comparative Study on the Physicochemical and Bacterial Analysis of Drinking, Borewell and Sewage
Water in the Three Different Places of Sivakasi. Journal Environmental Biology, 28, 105-108.

Schets, F. M., van Wijnen, J. H., Schijven, J. F., Schoon, H., and de Roda Husman, A. M. (2008). Monitoring of waterborne pathogens in surface waters in Amsterdam, the Netherlands, and the potential health risk associated with exposure to Cryptosporidium and Giardia in these waters. Applied and Environmental Microbiology, 74, 20692078.

Sivamanikandan, P., and Ahmed john, S. (2015). Impact of physico-chemical parameters on bacterial population in Mullaiperiyar River water-Theni district, Tamilnadu, India. Afr. $J$. Microbiol. Res, 9(1): 26-32

Sur, D. (2000). Severe cholera outbreak following floods in a northern district of West Bengal. Indian J. Med. Res, 112, 178-182.

Thompson, J.R; Randa, M.A; Marcelino, L.A; Tomita-Mitchell, A; Lim, E; Polz, M.F(2004). Diversity and dynamics of a north Atlantic coastal Vibrio community. Appl. Environ. Microbiol, 70, 4103-4110.

Till, D., McBride, G., Ball, A., Taylor, K., and Pyle, E. (2008). Large-scale freshwater microbiological study: Rationale, results and risks. Journal of Water and Health, 6(4), 443-460.

Vezzulli, L; Pezzati, E; Moreno, M; Fabiano, M; Pane, L; Pruzzo, C (2009). The Vibrio Sea Consortium. Benthic ecology of Vibrio spp. and pathogenic Vibrio species in a coastal Mediterranean environment (La Spezia Gulf, Italy). Microb. Ecol, 58, 808-818.

Wéry, N., Lhoutellier, C., Ducray, F., Delgenès, J. P., and Godon, J. J. (2008). Behaviour of pathogenic and indicator bacteria during urban wastewater treatment and sludge composting, as 
revealed by quantitative PCR. Water Research, 42, 53-62.

Wilkes, G., Edge, T., Gannon, V., Jokinen, C., Lyautey, E., Medeiros, D., et al. (2009). Seasonal relationships among indicator bacteria, pathogenic bacteria, Cryptosporidium oocysts, Giardia cysts, and hydrological indices for surface waters within an agricultural landscape. Water Research, 43, 2209-2223.

Wilkes, G., Edge, T., Gannon, V., Jokinen,
C., Lyautey, E., Medeiros, D., et al. (2009). Seasonal relationships among indicator bacteria, pathogenic bacteria, Cryptosporidium oocysts, Giardia cysts, and hydrological indices for surface waters within an agricultural landscape. Water Research, 43, 2209-2223.

Wray, C., and Wray, K. A. (2000). Salmonella in domestic animals. Oxon, UK: CABI Publishing.

\section{How to cite this article:}

Anurag Kumar, Jane Claryn Benjamin, Arti Kumari and Hemant Kumar. 2018. Isolation and Identification of Bacterial Strains from Yamuna River at Allahabad District in Uttar Pradesh, India. Int.J.Curr.Microbiol.App.Sci. 7(12): 3013-3022.

doi: https://doi.org/10.20546/ijcmas.2018.712.346 